\title{
Impact on Government Policy Prohibiting Export of Mining Products and Minerals Raw Materials
}

\author{
Bram B.Baan \\ Faculty of Law \\ Brawijaya University \\ Malang, Indonesia \\ braam.baan@yahoo.com
}

\begin{abstract}
This paper aims to analyze the impact of prohibiting the export of raw materials of mining products as mandated by Law Number 4 of 2009 concerning minerals and coal. Since the mining products are the non-renewable natural resource controlled by the state and used for the greatest prosperity of the people, the government seeks to boost the added value of minerals and mining products as set forth in Law Number 4 of 2009 concerning mineral and coal mining that regulates the obligation of refinement and management of mines and minerals within no later than 5 years. The impact of this policy is that from 2009-2014 mining companies conducted over-exploitation in order to avoid the prohibition to export the raw materials of mining products by the government. Therefore, it requires consistency from the mining companies to build smelters. To avoid the gap between the production of mining materials and the number of smelters, it is expected that all companies can be consistent in conducting the construction of smelter. The implication of the lack of smelter is that many non-salable raw material of mining products that will have an impact on reducing production capacity and this will therefore impact on reducing state revenues, reductions in labor and the erosion of the trade balance. The results of this study provide the benefit that the refining of minerals will provide added value and will provide additional revenue for the country.
\end{abstract}

Keywords - renewable mining and minerals, prohibition to export and construction of smelter

\section{INTRODUCTION}

As an archipelagic country, Indonesia is very rich in natural resources both in the sea and in land. The natural wealth in Indonesia is supposed to be well managed for the prosperity of the people of Indonesia. Considering to the concept of the welfare state as has been embraced by the state of Indonesia, it has become the duty of the Indonesian government to provide the welfare and prosperity of the people as has been conceptualized in the welfare state by well managing the natural resources.

Part of the natural resources that have the potential to improve the people's welfare is mining which includes Sumatra Island that has natural wealth of mining products such as petroleum, coal, copper, tin, granite, and some other mining products. The island of Borneo holds a wealth of mining in the form of coal and petroleum. Java Island has mining products in the form of petroleum, iron ore, granite, and other mining products. On the island of Sulawesi, the mining products are scattered, such as manganese, phosphate, copper, nickel and some other mining products; while the Moluccas and Papua, the easternmost islands of Indonesia, hold a wealth of petroleum, gold, silver and other mining products. Although mining companies consider Indonesia to have a bad investment climate however in fact Indonesia does have tremendous mineral potential and cannot be abandoned[1]. In order to regulate the mining sector, in 1967 the Indonesian government enacted Law Number 11 of 1967 concerning the Basic Provisions of Mining (the "Law No. 11 of 1967"). Law No.11 of 1967 also marks the open-door politics in the field of mining after previously preceded by the enactment of Law Number 1 of 1967 concerning Foreign Capital Investment (the "Law No. 1 of 1967")[2]. A long with the dynamics of post-reform thinking, Law No. 11 of 1967 is considered to be incompatible with the economic politics that wanted to be run by the government, especially in the field of mining. Therefore, the new Law was adopted as a substitute for Law No. 11 of 1967, namely Law Number 4 of 2009 concerning Mineral and Coal Mining (the "Law No.4 of 2009”).

In the management of natural resources, the Government should refer to the provisions of Article 33 Paragraph (3) of the Constitution of the Republic of Indonesia of 1945 which expressly mandates the earth and water and the natural resources contained therein shall be controlled by the state and utilized for the greatest prosperity of the people. Back to the mandate granted by the Indonesian Constitution of 1945 , Article 33 paragraph (3), the Constitutional Court provides an interpretation of the clause of "controlled by the state" which includes the meaning of control by the state in a broad sense derived from the sovereignty conception of the Indonesian people over all sources of the wealth of "earth and water and the natural resources contained therein", including the understanding of public ownership by the collectivity of the people over the source of the intended resources. The people in collective term was constructed by the Indonesian Constitution of 1945 that mandating the state to perform its functions in the conducting the policies (beleid) and the management action (bestuursdaad), the regulation (regelendaad), the management (beheersdaad), and the supervision (toezichthoudensdaad) by the state. Referring to this interpretation, mining products in Indonesia are controlled by the state managed for the welfare of the people as much as possible, as is the principle of welfare state.

In order to control the export of mineral ores and to push downstream industry, the government has issued 
Government Regulation Number 23 of 2010 which has been amended by Government Regulation Number 24 of 2012 concerning the implementation of Mineral and Coal Mining business activities. Subsequently several relevant regulations were is sued such as Regulation of the Minister of Energy and Mineral Resources Number 7 of 2012 which is then enhanced by the Regulation of the Minister of Energy and Mineral Resources Number 11 of 2012 concerning the Increase of Mineral Added Value through the Management and Refinement of Mineral (s melter) activities, where the material contained therein states that mining companies may export ores minerals overseas before 2014 if they have received recommendation from the Minister of Energy and Mineral Resources. Other relevant regulations that have been is sued in order to support the implementation of Mineral and Coal Mining Law are Regulation of the Minister of Trade Number 29 of 2012 concerning the Provisions on Export of Mining Products, and Regulation of the Minister of Finance Number 75 of 2012 concerning on Stipulation of Goods subject to Export Levy and Export Duty Tariff.

In relation to these issues, and pursuant to Letter of Request for Cooperation of Mining and Minerals Review from the Directorate of Export of Industrial and Mining Products (Directorate General of Foreign Trade) Number: 1022 DA GLU.3.4/ND/8/2013, dated 13 August 2013, then the Center for Foreign Trade Policy will conduct evaluation against the impact of the policy, especially in relation to the prohibition of export of raw in the form of ores on Mining and Mineral commodities which will be enacted in January 2014. Th is paper aims to find out how material the impact of the implementation of the government's policy to prohibit the exports of minerals and mining products in the form of ores (raw materials) through the Government Regulation Number 23 of 2010 as amended by Government Regulation Number 24 of 2012 concerning the Implementation of Mineral and Coal Mining Activities as well as its derivative regulations.

\section{DISCUSSION}

\section{Construction of Smelter}

Mineral and Coal Mining Law of 2009 requires mining commodities to be processed domestically before being exported. However, the Law provides exceptions to companies holding Contract of Work (COW) and Coal Mining Concession Working Agreement (Indonesian: Perjanjian Karya Pengusahaan Pertambangan Batubara (the "PKP2B") to carry out such obligations by 2014. For the Indonesian government, the five years to 2014 is more than enough to realize one hundred percent of the downstream policy... the Construction of Smelter. In fact, after three years since the Mineral and Coal Mining Law is proclaimed, namely since 2012, the domestic processing and refinement activities have not showed significant progress. Conversely, mineral and coal exploration is so massive that the export volume of raw minerals increases. The Directorate General of Mineral and Coal even mentioned that there are number of mineral commodities which completely have no domestic processing factories [4].

So far, the import of mineral and mining product of Indonesia are in the form of processed mine where in fact the natural resources in Indonesia have all the raw materials of the mine. For example, the import of alumina as the basic material of aluminum. In terms of material, this country must have a strong base industry as a supporting industry that processes raw materials into raw or auxiliary materials or semi-fin ished goods or which produce energy for domestic industrial purposes. Moreover, the directed industrial downstream wants to achieve strategic objectives, among others, reduce import dependence and strengthening the industrial structure in the country. Ideally, the industry downstream program will only be realized in the long term if the government can develop its policy in two major areas, namely the policy of developing basic industry as supporting industry and downstream industry policy itself

The follow up of the Mineral and Coal Mining Law will likely provide an opportunity for employers to import raw mineral materials if the availability of smelters is sufficient in Indonesia. This is because the supply of raw materials to the smelter must be maintained and continued so that the production value will not stop and remain to have economic value, and since the smelter requires not small-raw material and production in the factory cannot be stopped. If the smelter has been built domestically, Indonesia will be a good market for mineral-producing countries so that Indonesia will no longer need to import the processed minerals from other countries, besides the construction of Smelter by mining companies will open employment opportunities for the Indonesian society.

On the other hand, the government, through the Ministry of Trade, has also issued the Regulation of the Minister of Trade No. 29/M-A G/PER/5/2012 as has been amended by Regulation of the Minister of Trade No. 52/MAG/PER/8/2012 concerning Provisions on the Export of Mining Products, which governs matters relating to the procedures and permissions for the implementation of export activities of various types of mining products taking which shall consider the necessity to fulfill minimum processing limits. The impact of the prohibition on the exports of raw material and the slow pace of smelter construction will have an impact on the number of non-salable mining raw materials, and ultimately leading miners to reduce their production capacity or even close their businesses. This condition will result in reduced state revenues, reduced employment in the mining sector, further erosion of the trade balance.

As an effort to increase the sale value of mining products, the Mineral and Coal Mining Law stipulates the obligation to refine the mining products domestically, such obligation as contained in Article 102 and Article 103 of Mineral and Coal Mining Law. Article 102 of Mineral and Coal Mining Law stipulates that "The holders of Mining Business License and Special Mining Business License shall be obliged to increase the added value of mineral resources and/ or coal resources in the implementation of mining, processing and refinement, and the utilization of minerals and coal." Whereas Article 103 of Mineral and Coal Mining Law stipulates that:

1) Holders of holders of Mining Business License and Special Mining Business License - Production Operations are obliged to conduct the sorting and refining ofmining products domestically.

2) Holders of holders of Mining Business License and Special Mining Business License as referred to in paragraph (1) may sort and refine mining production 
of other holders of holders of Mining Business License and Special Mining Business License.

3) Further provisions concerning the increase of value added as referred to in Article 102 as well as the processing and refining as referred to in paragraph (2) shall be regulated by the government regulation.

By the existence of such rules, it is obligatory for every mining company to sort and refine domestically or in Indonesia before to export the same abroad. The rules concerning the sorting and refinement apply not only to the holders of Mining Business License and Special Mining Business License however they apply as well to the holders of contract of work; this is as regulated in the provision of Article 170 of Mineral and Coal Mining Law that "The holders of the contract of work as referred to in Article 169 that have made production shall be obliged to conduct refinement as referred to in Article 103 paragraph (1) not later than 5 (five) years since the enactment of Law". This is confirmed by the Government Regulation No. 1 of 2014 that every holder of contract of work who has conducted refinement in domestic may perform overseas sales.

The government also explained that the main purpose of increasing value added shall not inhibit the trade but utilizing mineral and national wealth for the greatest prosperity of the nation. This effort cannot be postponed because the mineral wealth will be exhausted at one time and cannot be renewed. Increased prosperity can be achieved if there is an increase in economic activity along the chain of mineral production. Increased domestic production chains will in turn have a positive impact on the economy in the form of output creation, added value and domestic employment, and in addition according to the government, the availability of downstream raw materials of domestic metal-based industries, as well as the mastery of technology in mineral management. That the development of mining industry will strengthen the national industry which will have a wider impact and the opening of employ ment in all fields, which is certainly the manifestation of the mandate of Article 27 Paragraph (2) of the Constitution of the Republic of Indonesia of 1945. In addition, by the existence of industrial management and refining, then the Indonesian people not only sell raw materials, it will have an impact on increasing state revenues that can to improve the people's welfare budget, public services, rural infrastructure, management industry will also produce advanced materials that will provide support for other national industries which rely on the results of management and others.

The enactment of the regulation of the prohibition of exports of raw materials, of course, bring many challenges from industry players, but they should be able to use the constitutional channels in rejecting the prohibition by conducting a judicial review to the Constitutional Court as a legal entity which constitutional rights is impaired. In early 2017, the government issued Regulation of the Minister of Energy and Mineral Resources Number 5 of 2017 (the "Regulation of the Minister of Energy and Mineral Resources 5/2017'). The regulation opens opportunities for low grade nickel ore exports, namely below 1.7 percent, and washed bauxite with A12O3 content of more than 42 percent.[5] The reason for the issuance of the rule is that the domestic smelters mostly only process nickel above 1.7 percent and bauxite with A12O3 content of more than 42 percent. As a result, low grade nickel and bauxite grade
A12O3 above 42 percent is wasted. Finally, the product is exported to generate revenue for the country.

The is suance of Regulation of the Minister of Energy and Mineral Resources No. 5 of 2017 is a manifestation of the inconsistency of the government in carrying out the mandate of Law No. 4 of 2009 along with its derivative rules without conducting a thorough analysis, this regulation would create legal uncertainty for both domestic investors and foreign investment investors because the government does not seem to have a long-term program in the minerals and coal industries.

\section{Potential Business Close and Termination of employment}

Every new regulation, always causing a victim or a victimized party, however as we look at the prohibition on the importation of raw materials of mining products, the mining entrepreneurs should be prepared from the very beginning to anticipate the implementation of the downstream regulations of materials derived from mining in anticipation to deal with them. as follows: First, government revenue is potentially plummeted because many mining companies prefer to close their business. This factor is not the only cause of many mining operations close, amid the eruption of world oil prices greatly impact on the current low price of mining products. Government revenue derived from the mining sector can be tax revenue (tax), the dead-rent and non-tax revenue (mining royalties), but those escaped from government monitoring is that the true potential tax loss is a significant contribution coming from the unlicensed mining companies which number, certainly, are hundreds and their potential exploration results are very large. Second, the reduced of mine production will have implications for reducing the labor. There are currently many mining sector workers who are laid off earlier than expected. The drop-in mining prices and the prohibition on raw material exports makes the government to be obliged to provide another solution to the current policy. Another impact of the reduction of manpower will also occur in mining supporting companies, such as shipping and heavy equipment. Third, the non-oil and gas mining sector (including mineral and coal mining) contributes substantial government revenues to the state budget. If exports of raw materials decline due to export prohibition and falling oil prices, the trade balance will become increasingly deficit. This will affect the weakening of the rupiah exchange rate that boosts import costs. The high cost of imports will affect some products that still rely on imported components.

These three impacts are now being experienced by the Indonesian government against the policy of the prohibition of the exports of raw materials. Of course, this is already in the careful attention by the government with all the solutions. Every policy must have its good and its shortcomings, for sure the government has made a very good decision to start the mining industry. This policy will be disadvantageous for now, but it will be very profitable in the future. It is considering that the raw mineral is a large segment so far in supporting Indonesian exports (about 3 percent of total nonoil and gas exports)[6]. So with the policy of the termination will affect the value of Indonesian exports. Estimated decline by 9.2 percent. The decline in the value of exports in large numbers provides significant losses to the state revenue. The mineral and coal sub-sector currently serves as a major support for Indonesia's development, especially in terms of sources of state revenues, regional development drivers, 
trade balance, investment and employ ment, but as explained above that in making decisions the government has conducted a major in-depth analysis since Law No. 4 of 2009 concerning minerals and coal has been made to think about the impact that will arise in the future, but what we missed is before the export prohibition begins to apply the government should, 2 or 3 years in advance, has massively give appeal and information to mining company in order to ensure they are ready with all of their tools, especially in terms of the construction of smelter, so that by early 2014 all mining companies should be ready.

With more companies construct the Smelter in fact also left a new problem; in 2016 as many as 26 Smelter closed and in 2017 also reported that as many as 11 smelters closed again because of the run out of raw materials; by the closing of the smelter, it is of course also will be followed by the reduction of manpower, but it can be assured that this will not happen forever, this issue is more caused by the mining operators that reducing their production due to falling prices on world markets.

\section{CONCLUSION}

Implementation of Law Number 4 of 2009 has not been fully adhered to by the mining entrepreneurs, it should be within five years the entrepreneurs/companies can prepare themselves in terms of the construction of Smelter and of course the government's role to continue in evaluating the construction of Smelter is needed; however it is as if that the government is afraid and barely have enough power to infiltrate the entrepreneurs/companies who have not obeyed the rules until the time comes, even the government shows inconsistency by issuing Regulation of the Minister of Energy and Mineral Resources No. 5 year 2017 which opens tap export of nickel ores. To improve the dignity of the government then the government should be consistent in applying legislation that has been made and mutually agreed.

\section{REFERENCES}

[1]. Victor Imanuel Nalle. The right to control by the State on Mineral and Coal after the enactment of Mineral and Coal Mining Law. Constitutional Journal, Volume 9 No. 3, September 2012

[2]. Salim HS. Mining Law In Indonesia. Jakarta, PT Raja Grafindo Persada 2006

[3] Law of the Republic of Indonesia Number 4 of 2009 concerning Mineral and Coal

[4]. Internal Magazine of PT Vale Indonesia Tbk, Mineral and Coal Mining Law Pursuing Added Value, Jakarta, 2014

[5]. Industriamagz.com Connecting \& Promoting Industry, Taps Export opened, 20 Smelter Nickel closed.

[6]. Prohibition of Export of Raw Minerals. Accessed via http://www.idedunia.com/2015/09/larangan-ekspormineralmentah.html. Accessed on 10 July 2018, Accessed at 9.30 a.m. Western Indonesian Time, on July 25, 2018 